\title{
KEKUATAN MILITER DAN DIPLOMASI NEGARA DI TINGKAT KAWASAN (PERBANDINGAN INDIA DENGAN INDONESIA)
}

\author{
Luerdi \\ Mahasiswa Pascasarjana Ilmu Politik Universitas Riau
}

\section{Citation as}

Luerdi, L. (2014). Kekuatan Militer dan Diplomasi Negara di Tingkat Kawasan (Perbandingan India dengan Indonesia). https://doi.org/10.31219/osf.io/vpcug 


\title{
Kekuatan Militer dan Diplomasi Negara di Tingkat Kawasan (Perbandingan India dengan Indonesia) ${ }^{1}$
}

\author{
Luerdi \\ Mahasiswa Pascasarjana Ilmu Politik Universitas Riau
}

\section{Pendahuluan}

Tulisan ini merupakan perbandingan kekuatan militer dan diplomasi dua negara besar di kawasan. Tulisan ini berupaya menghubungkan kekuatan militer negara dengan kekuatan diplomasi yang dimiliki oleh negara tersebut. Adapun negara yang dibahas dalam tulisan ini adalah India dan Indonesia. Baik India dan Indonesia adalah negara demokrasi besar, masing-masing menempati urutan kedua dan ketiga di dunia. India adalah salah satu kekuatan di kawasan Asia Selatan, sedangkan Indonesia adalah salah satu kekuatan di kawasan Asia Tenggara.

Namun, lingkungan yang dimiliki India di Asia Selatan dan yang dimiliki Indonesia di Asia Tenggara berbeda sehingga memberikan cara pandang yang berbeda pula terhadap kebutuhan peningkatan kekuatan militer yang dimiliki oleh kedua negara tersebut. Ini berkaitan dengan sejauh mana kekuatan militer dianggap penting oleh kedua negara di tingkat kawasan dan bagaimana interaksi kedua negara tersebut dengan negara-negara tetangganya.

Walaupun demikian, kedua negara tersebut tetap dianggap sebagai kekuatan penting dalam dinamika politik dan stabilitas keamanan di kawasan masing-masing. Kedua negara sama-sama terus berupaya meningkatkan kabapibilitas militernya agar semakin diperhitungkan di tingkat kawasan

\footnotetext{
${ }^{1}$ Bahan diskusi perkuliahan pada Program Studi Ilmu Politik Pascasarjana Universitas Riau (2013-2014).
} 
masing-masing, tapi dalam level yang berbeda karena perkembangan militer suatu negara berjalan seiring dengan kekuatan ekonomi negara tersebut.

Sebelum melakukan analisis kekuatan militer dan diplomasi antara India dan Indonesia, penulis mencoba menyajikan data kekuatan militer, alokasi dana untuk pertahanan, dan kondisi geografis kedua negara seperti yang terlihat dibawah ini: ${ }^{2}$

MANPOWER (INDIA/INDONESIA)

Total popopulation

$: 1,220,800,359 / 251,160,124$

Active frontline personnel

$: 1,325,000 / 476,000$

Active reserve personnel

$: 2,143,000 / 400,000$

LAND SYSTEMS (INDIA/INDONESIA)

Tanks

$: 3,569 / 374$

Armoured fighting vehicles (AFV)

: 5,085/1,172

Self-propelled guns (SPG)

$: 290 / 91$

Towed-artillery

$: 6,445 / 94$

Multiple-launch rocket system (MLRS)

: $292 / 84$

AIR POWER (INDIA/INDONESIA)

Total aircraft

$: 1,785 / 381$

Fighters/interceptors

$: 535 / 29$

Fixed-wing attack aircraft

: $468 / 56$

Helicopter

Attack helicopters

$: 504 / 49$

$: 20 / 5$

NAVAL POWER (INDIA/INDONESIA)

Aircraft carriers

$: 2 / 0$

Frigates

$: 15 / 0$

Destroyers

$: 11 / 0$

Submarines

$: 17 / 2$

Coastal defence craft

$: 32 / 84$

Mine warfare

$: 7 / 12$

FINANCIAL IN USD (INDIA/INDONESIA)

Defence budget

$: \$ 46 b / \$ 7.5 b$

${ }^{2}$ The World's States' Military Power 2014 (India, Indonesia), http://www.globalfirepower.com/countries-

listing.asp?fb_action ids $=653603291384975 \& \mathrm{fb}$ action_types $=0$ g.likes\&fb_source $=$ aggregatio n\&fb_aggregation_id $=288381481237582$, pada tanggal 17 Juni 2014. 
GEOGRAPHY (INDIA/INDONESIA)

Square land area

Coastline

:3,287,267 km / 1,904,569 km

Shared border

Waterways

: 7,000 km / 54,716 km

: $14,103 \mathrm{~km} / 2,830 \mathrm{~km}$

: $14,500 \mathrm{~km} / 21,579 \mathrm{~km}$

Sedangkan untuk persenjataan nuklir, India telah mengembangkan persenjataan nuklir sejak lama dan kini menjadi negara nuklir terbesar setelah Cina di Asia. Sulit untuk menentukan jumlah pasti persenjataan nuklir negaranegara di dunia, tapi India diperkirakan memiliki sekitar 90 hulu ledak nukir (warhead). ${ }^{3}$ India juga diperkirakan memiliki paling sedikit 8 reaktor penelitian dan 13 power reactor nuklir yang digunakan baik untuk kepentingan militer ataupun sipil. 4

India juga telah mengembangkan berbagai land-based missile berkekuatan nuklir yang diberi nama Prithvi 150, Prithvi 250, Prithvi 350, Agni dan Surya. 5 Sedangkan Indonesia tidak memberikan perhatian terhadap pengembangan nuklir bagi pertahanannya, sehingga Indonesia tidak memiliki persenjataan militer berkekuatan nuklir. Pertimbangan Indonesia untuk tidak mengembangkan persenjataan nuklir didorong oleh karakter kawasan Asia Tenggara yang cenderung menghindari pengembangan persenjataan nuklir.

Tulisan ini berupaya menjawab pertanyaan: 1) Bagaimana perbandingan kekuatan militer India dengan Indonesia, dan faktor-faktor apa saja yang mempengaruhi perkembangan kekuatan militer kedua negara tersebut?, 2) Sejauh mana kekuatan militer mempengaruhi dilplomasi India dan Indonesia dalam upaya mempertahankan kedaulatan nasional dan stabilitas kawasan?

\footnotetext{
${ }^{3}$ Top 10 Military Powers of the World, http://www.buzzle.com/articles/top10-military-powersof-the-world.html, pada tanggal 17 Juni 2014.

${ }^{4}$ Indian Nuclear Facilities dalam Luerdi., Kebijakan Keamanan Nasional Pakistan Sebagai Respon Perjanjian Nuklir Sipil India-AS, Skripsi, Jurusan Ilmu Hubungan Internasional Universitas Riau, 2008, hal. 63-64.

${ }^{5}$ Tracking Nuclear Proliferation, dalam Luerdi, ibid., hal 65.
} 


\section{Pendekatan Teoritis}

Penulis menggunakan tingkat analisa negara-bangsa (nation-state analysis) dalam tulisan ini. Tingkat analisa ini menekankan pada asumsi bahwa semua pembuat keputusan dimanapun berada, pada dasarnya berperilaku sama apabila menghadapi situasi yang sama. Negara merupakan aktor yang paling kuat, dominan, dan relatif bebasa dalam membuat kebijakan dalam percaturan interaksi di pentas dunia. Menurut John T. Raorke, negara pada hakikatnya adalah aktor yang mengendalikan sistem internasional termasuk negara kecil dan paling lemah sekalipun. ${ }^{6}$

Perilaku negara berdasarkan pandangan bahwa banyak peristiwa politik dunia terjadi sekitar interaksi antar pemerintah dua negara atau lebih dapat dijadikan fenomena untuk menukur alasan rasional dibelakang tindakan negara lain dan mengantisipasi gerak berikutnya.7 Adapun negara-negara yang dimaksudkan oleh penulis dalam tulisan ini adalah India dan Indonesia.

Untuk menjelaskan permasalahan dalam tulisan ini, penulis mengunakan teori realisme (realism theory) sesuai dengan tingkat analisa negara-bangsa. Pendekatan realisme termasuk dalam aliran pemikiran tradisional yang paling tua dalam sejarah pemikiran politik hubungan internasional. Teori ini menjadikan negara-negara sebagai unit analisa utama (main unit of analysis). ${ }^{8}$ Menurut Kenneth Walts, negara-negara merupakan aktor terpenting dalam interaksi hubungan internasional dimana proposisi teoritis utama mengarah pada kompetisi kepentingan negara-negara secara konstan untuk mendapatkan power atau keamanan. ${ }^{9}$ Sedangkan menurut Stephen Krasner, Realisme merupakan teori politik internasional dan

\footnotetext{
${ }^{6}$ Luerdi, ibid, hal.16-17.

7 Ibid.,

${ }^{8}$ lbid.,

9 lbid., hal. 18
} 
merupakan sebuah upaya menjelaskan tingkah laku tiap negara dan karakteristik sistem internasional secara keseluruhan. ${ }^{10}$

Realisme memberikan perhatian utama pada isu ancaman dan keamanan dalam sistem dunia yang anarkis. Terkait masalah ancaman, Krasner mengatakan bahwa negara-negara berdaulat merupakan para aktor rasional mandiri yang sangat concern dengan keutungan relatif karena mereka harus berfungsi dalam sebuah lingkungan anarkis dimana keamanan dan keadaan mereka sangat bergantung pada kemampuan mereka memobilisasi sumber daya untuk melawan ancaman-ancaman luar. ${ }^{11}$ Dengan memahami penjelasan diatas, setiap negara pada dasarnya akan melakukan berbagai kebijakan dan tindakan untuk melindungi dirinya dari ancaman negara lain atau lingkungannya.

Realisme menekankan pada perlunya keberadaan power. Morgenthau mengatakan bahwa inti dari hubungan internasional adalah politik internasional yang berusaha memperjuangkan power antar negara bangsa sehingga semua pemerintah nasional disibukkan oleh kegiatan-kegiatan memperjuangkan power. ${ }^{12}$ Hubungan internasional baik itu kerjasama, persaingan, dan konflik antar aktor menunujukkan adanya hubungan atau keterlibatan power. Power dapat dilihat dengan memahami perilaku suatu aktor terhadap aktor lainnya.

Secara realitas power hanya terlihat dalam tindakan-tindakan. Oleh karena itu unsur-unsur power juga akan tampak pada tindakan-tindakan si pemilik power yang menunjukkan adanya kemampuan karena adanya potensi dan kapasistas untuk melakukan tindakan-tindakan tersebut. ${ }^{13}$ Power secara umum dipahami sebagai kemampuan suatu negara untuk merubah persepsi

\footnotetext{
${ }^{10}$ Martin Griffits., Lima Puluh Pemikir Studi Hubungan Internasional, Edisi ke-1, PT.Raja Grafindo Persada, 2001, Jakarta, hal. 42.

${ }^{11}$ Ibid.,

${ }^{12}$ R.Soeprapto., Hubungan Internasional; Sistem, Interaksi dan Perilaku, PT. Raja Grafindo

Persada, Jakarta, 1997, hal. 120.

13 lbid, hal.122.
} 
dan perilaku negara lain, upaya tersebut dapat melalui force, influence, ataupun authority.

Dalam konsep realisme, unsur power yang paling dibutuhkan oleh setiap negara adalah kapabilitas militer. Bagi negara-negara besar, kapabilitas militer dibutuhkan untuk mempertahankan status quo atau memperluas pengaruh terhadap negara-negara lain. Sedangkan bagi negara-negara menengah atau kecil, kapabilitas militer dibutuhkan untuk pertahanan nasional, yaitu melindungi kedaulatan nasional dari ancaman pihak luar. Selain itu power militer juga dimaksudkan untuk mengimbangi kekuatan suatu pihak (balance of power) atau mencegah suatu negara menjadi hegemon di tingkat kawasan dan menciptakan stabilitas di kawasan tersebut.

Upaya untuk meningkatkan kapabilitas militer dapat dilakukan dengan berbagai cara seperti meningkatkan kuantitas dan kualitas personil dan peralatan militer mulai dari persenjataan, tank, pesawat tempur, kapal selam, sampai pada senjata nuklir secara mandiri atau dengan cara melakukan kerjasama dengan negara yang lebih besar. India dan Indonesia memiliki jurang yang sangat lebar dalam kapabilitas power militer yang dimiliki karena adanya perbedaan sumber daya dan persepsi. Namun kedua negara memiliki keinginan yang sama untuk melindungi kedaulatan nasional dari ancaman pihak luar.

Diplomasi adalah salah satu alat (instrument) politik luar negeri yang paling banyak dipraktikkan oleh negara-negara di dunia saat ini. Diplomasi memiliki image berupa perjuangan untuk meraih kepentingan nasional dengan cara damai. Diplomasi meliputi berbagai isu, mulai dari pembicaraan yang berkaitan dengan kerjasama perdagangan sampai pada pembicaraan penyelesaian konflik berdarah sekalipun.

Menurut DR.Budiono, diplomasi memikul tugas-tugas politik sebagai suatu intrumen, seperti: 1) meniadakan suatu keadaan yang merugikan kepentingan nasional, 2) mempertahankan keadaan yang menguntungkan 
kepentingan nasional, 3) menegakkan keadaan yang diperlukan demi kepentingan nasional. ${ }^{14}$ Artinya, setiap negara memberikan perhatian terhadap diplomasi yang dilakukan karena menyangkut kepentingan nasionalnya.

S.L. Roy menggambarkan bahwa penyelesaian masalah internasional tidak selalu dilaksanakan sepenuhnya dengan hal-hal yang bisa diterima akal dan kemampuan bernegosiasi. ${ }^{15}$ Unsur yang paling esensial yang bisa digunakan suatu negara untuk menjamin kepentingan vitalnya adalah keefektifan power yang ia pegang. Kekuatan militer sebagai suatu pemaksa atau alat kekerasan, merupakan bagian yang inheren dari diplomasi dalam suatu negara yang anarki.

Seorang diplomat yang sangat kompeten di bidangnya bisa saja mengalami kegagalan bila negaranya tidak mempunyai kekuatan yang memadai guna mendukung tuntutannya. ${ }^{16}$ Dengan melihat argumen Roy diatas dapat dipahami bahwa kapabilitas militer India dan Indonesia mempengaruhi derajat kekuatan diplomasi kedua negara tersebut di kawasan dan membentuk persepsi negara-negara tetangga mereka terhadap power kedua negara tersebut.

\section{Analisa Perbandingan Kekuatan Militer dan Diplomasi India dengan Indonesia di Tingkat Kawasan.}

India adalah kekuatan penting di kawasan Asia Selatan dan begitu pula dengan Indonesia di kawasan Asia Tenggara. Namun kedua negara tersebut memiliki perkembangan militer yang berbeda. India telah mengalami perkembangan militer yang jauh lebih cepat ketimbang Indonesia. Ada beberapa faktor yang mempengaruhi perkembangan militer kedua negara

\footnotetext{
14 Ibid., hal.212.

15 S.L. Roy., Diplomasi, Edisi ke-1, Rajawali Pers, Jakarta, 1991, hal. 20.

16 Ibid.,
} 
tersebut, seperti latar belakang sejarah, karakter kawasan, dan kekuatan ekonomi.

Latar belakang sejarah merupakan faktor terpenting yang menjadi pertimbangan pemerintah suatu negara untuk mengembangkan kemampuan militer nasional negaranya. India memiliki sejarah konflik dengan Pakistan sejak negara tersebut memisahkan diri dari India. Pakistan adalah musuh historis India dan India menyadari bahwa Pakistan dapat mempengaruhi dinamika politik kawasan Asia Selatan walaupun negara tersebut hanyalah sebagai negara kecil yang kapabilitas militernya jauh lebih rendah. Walau demikian, India tetap menganggap Pakistan bisa saja menjadi ancaman nyata bagi keamanan nasionalnya, begitu pula dengan Pakistan yang menganggap India sebagai ancaman karena India memiliki kapabilitas militer yang jauh lebih kuat.

India dan Pakistan telah tiga kali terlibat konflik bersenjata dengan Pakistan dalam perebutan wilayah Kashmir yang menyebabkan wilayah tersebut terbelah. ${ }^{17}$ Adanya persepsi ancaman dari masing-masing pihak, mendorong kedua negara meningkatkan kekuatan militernya. Peningkatan kekuatan militer yang dilakukan oleh India dan Pakistan tidak hanya dalam hal persenjataan konvensional tapi juga pengembangan senjata nuklir. Pada tahun 1998, kedua negara melakukan ujicoba senjata nuklir sebagai wujud show of force dan membuat khawatir negara-negara lain di kawasan Asia Selatan dan dunia internasional. ${ }^{18}$

Selain karena Pakistan dianggap sebagai ancaman potensial di masa yang akan datang, India juga menilai Pakistan sebagai negara yang tidak stabil dimana konflik politik sering terjadi di negara tersbut dan Pakistan menjadi wilayah subur bagi berbagai kelompok ekstrimis. India khawatir bila Pakistan menjadi basis gerakan ekstrimis yang membahayakan kedaulatandan

\footnotetext{
${ }^{17}$ Luerdi., Op.Cit., hal. 60.

${ }^{18}$ Ibid., hal.2.
} 
rakyatnya. India juga khawatir bila persenjataan nuklir Pakistan jatuh ketangan pihak-pihak yang tidak bertanggungjawab yang dapat diarahkan pada India.

Kawasan Asia Selatan juga menjadi kawasan persaingan antara Amerika Serikat dan Cina. AS menyadari bahwa Cina berambisi memperkuat pengaruh di kawasan tersebut. Perkembangan militer dan nuklir India tidak dapat lepas dari bantuan AS. India dan Cina pernah terlibat dalam perang memperebutkan perbatasan (Sino-India War) dan dalam perang ini India mengalami kekalahan. India menyadari bahwa Cina sebagai ancaman bagi kedaulatannya selain Pakistan. India menjadikan AS sebagai pihak yang dapat diandalkan dalam membantu meningkatkan power militernya untuk mengimbangi kekuatan militer Cina. Namun Cina juga membantu meningkatkan kekuatan militer Pakistan untuk menciptakan keseimbangan di kawasan Asia Selatan. Perkembangan kekuatan nuklir di kawasan Asia Selatan tidak dapat dipisahkan oleh peran-peran yang dimainkan oleh AS dan Cina. ${ }^{19}$

India menyadari power militer merupakan suatu kebutuhan untuk melindungi keamanan dan kedaulatan nasionalnya. Sejak berakhirnya Perang Dingin, India telah melakukan peningkatan kapabilitas militer yang begitu signifikan mengingat karakter Asia Selatan yang menyimpan konflik potensial antara India dengan Pakistan, stabilitas Pakistan yang tak menentu, dan kawasan tersebut menjadi arena persaingan kekuatan AS dan Cina.

Berbeda dengan kawasan Asia Tenggara. Negara-negara di Asia Tenggara tidak memiliki latar belakang sejarah konflik seperti halnya di Asia Selatan. Berbagai konflik seperti konflik perbatasan yang terjadi antar negara di Asia Tenggara dapat diselesaikan atau setidaknya dibicarakan dengan caracara non-kekerasan. Latar belakang seperti ini mempengaruhi cara pandang atau persepsi pemerintah Indonesia dalam meningkatkan kemampuan militernya. Indonesia tetap memandang perlu untuk meningkatkan kekuatan militer namun upaya tersebut tidak seambisius India. Indonesia lebih meyakini

\footnotetext{
${ }^{19}$ Ibid., hal 9-10.
} 
bahwa peluang terjadinya perang dengan negara lain di Asia Tenggara sangatlah kecil. Selain itu negara-negara di kawasan ini telah sepakat untuk menjaga stabilitas keamanan dan menghindari penggunaan militer dalam penyelesaian masalah dibawah payung organisasi ASEAN.

Kekuatan ekonomi juga menentukan derajat peningkatan kekuatan militer suatu negara. Negara yang mengalami pertumbuhan ekonomi yang relatif lebih baik, akan mampu meningkatkan kekuatan militernya dengan relatif lebih cepat. India adalah kekuatan ekonomi baru di dunia yang memiliki pertumbuhan ekonomi yang mengagumkan selain Cina, Brazil, Afrika Selatan, dan Turki. Pertumbuhan ekonomi yang dialami India memungkinkan negara ini meningkatkan kekuatan militernya. India mampu mengalokasikan dana sebasar lebih kurang 46 milyar dollar AS untuk kebutuhan militer nasionalnya. ${ }^{20}$

India adalah negara pengimpor persenjataan terbasar di dunia saat ini, sebagian besar pembelian persenjataan tersebut berasal dari Rusia dan selebihnya dari Inggris, Israel, AS, Italia, dan negara lainnya. ${ }^{21}$ Saat ini India juga menjadi negara ke-tujuh terbesar di dunia dalam menghabiskan anggaran untuk kebutuhan militer dan diperkirakan akan menjadi negara dengan kekuatan militer terbesar ke-empat menjelang akhir dekade ini. ${ }^{22}$ India tidak hanya mengimpor persenjataan dari negara lain tapi juga memproduksi sendiri di dalam negeri. India juga sedang mengembangkan kapal perang berkekuatan nuklir dalam negeri yang mencoba menerapkan teknologi persenjataan yang mirip dengan AS. ${ }^{23}$

Sedangkan kekuatan ekonomi Indonesia tidak sebesar India sehingga alokasi dana untuk kepentingan militer jauh lebih kecil dari India.

\footnotetext{
20 The World's States' Military Power 2014., Loc.Cit.,

${ }^{21}$ India as a great power., http://www.economist.com/news/briefing/21574458-india-poisedbecome-one-four-largest-military-powers-world-end, tanggal 16 Juni 2014.

22 Ibid.,

${ }^{23}$ Indian Navy developing new stealth ships., India Breaking News, http://www.youtube/IndianNavy-developing-new-stealth-ships/, tanggal 16 Juni 2014
} 
Pertumbuhan ekonomi yang dialami oleh Indonesia hanya mampu memberikan kurang dari 1,5\% dari GDP, atau sebesar lebih kurang dari 8 milyar dollar AS untuk kebutuhan militernya. ${ }^{24}$ Realitas kekuatan ekonomi Indonesia seperti ini mendukung alasan tidak signifikannya perkembangan power militernya di kawasan Asia Tenggara. Walau demikian, Indonesia mulai mampu memproduksi berbagai perlengkapan militer seperti tank dan persenjataan untuk kebutuhan pertahanan nasional dan ekspor ke luar negeri.

Dengan mempertimbangkan luas wilayah dan melihat kekuatan militer yang dimiliki oleh kedua negara tersebut, India nampaknya lebih mampu mempertahankan kedaulatan teritorialnya secara lebih efektif ketimbang Indonesia dalam mempertahankan kedaulatan teritorialnya. India telah memiliki setidaknya tiga basis angkatan laut utama yang ditempatkan di daerah dekat pantai negara tersebut untuk mengantisipasi kemungkinan serangan yang datang dari samudera Hindia. ${ }^{25}$ Kekuatan angkatan laut Indonesia yang masih terbatas belum mampu menjaga wilayah kedaulatannya secara maksimal yang berbentuk kepulauan, terdiri dari lebih 17 ribu pulau, dan sebagian besar wilayah kadaulatan tersebut terdiri dari lautan.

Lalu bagaimana dengan kekuatan militer India dan Indonesia dalam mempengaruhi kekuatan diplomasi di tingkat kawasan masing-masing? India sebagai negara besar di Asia Selatan dan memiliki senjata nuklir nampaknya memiliki kemampuan diplomasi yang diperhitungkan oleh Pakistan dan Cina yang juga sama-sama memiliki senjata nuklir. Walaupun India menganggap Pakistan sebagai musuh historis, India mampu membawa Pakistan pada kesepakatan gencatan senjata untuk menghindari perang terbuka.

Sedangkan diplomasi India terhadap Cina, khususnya dalam konflik perbatasan masih belum tuntas sampai sekarang. Namun setidaknya India dapat menggiring Cina untuk tidak menggunakan cara kekerasan dalam

\footnotetext{
${ }^{24}$ Trefor Moss., Indonesia Military Powers Up, http://www.thediplomat.com/Indonesia-MilitaryPowers-Up, tanggal 16 Juni 2014.

25 India as a great power, Loc.Cit.,
} 
penyelesaian konflik perbatasan. Bagi negara-negara tetangga India lainnya, seperti Bangladesh, Srilanka, dan Nepal, India dianggap memiliki peran penting dalam menjaga stabilitas kawasan. India juga memiliki citra sebagai kekuatan militer yang berpengaruh didukung oleh kekuatan ekonominya sehingga India lebih mudah untuk mempengaruhi negara-negara tersebut.

Indonesia adalah negara paling besar berbentuk kepulauan di kawasan Asia Tenggara. Kapabilitas militernya belum dapat menjaga dan mengawasi seluruh kedaulatannya khususnya pulau-pulau terluar. Perkembangan militer Indonesia tidak sebanding dengan luasnya wilayah kedaulatan dan geografis medan yang dimiliki. Dalam beberapa kasus sengketa teritorial dengan Malaysia, kekuatan militer Indonesia di laut cenderung kalah dengan kekuatan militer Malaysia.

Keterbatasan Indonesia dalam kemampuan melindungi seluruh kedaulatannya mempengaruhi persepsi negara-negara tetangga akan power yang dimiliki Indonesia. Dalam berbagai diplomasi terkait penyelesaian sengketa pulau-pulau terluar, Indonesia hanya mampu mengusulkan penurunan derajat ketegangan dengan Malaysia. Sementara Malaysia lebih percaya diri menghadapi Indonesia dan cenderung menginginkan sengketa pulau-pulau terluar dibawa ke Arbitrase Internasional.

Dalam penyelesaian sengketa gugusan kepulauan di Laut Cina Selatan antara beberapa negara ASEAN dengan Cina, Indonesia cenderung mengedepankan proposal cara-cara damai untuk mengfasilitasi pihak-pihak yang bersengketa. Indonesia selalu tampil netral atau tidak memihak salah satu pihak. Namun ada keinginan negara-negara ASEAN yang bersengketa dengan Cina terkait klaim pulau-pulau di Laut Cina Selatan (Spratley dan Paracel) agar negara-negara ASEAN lainnya khususnya Indonesia, menunjukkan solidaritas dan dukungan terhadap mereka dalam menghadapi Cina dengan lebih efektif. Namun mengingat power militer yang dimiliki oleh 
Indonesia dan negara-negara ASEAN lainnya sangat jauh berada dibawah Cina, kemungkinan untuk menekan Cina sangatlah kecil untuk saat ini.

\section{Kesimpulan}

Dengan melihat perbandingan power militer dan kekuatan diplomasi India dengan Indonesia di tingkat kawasan masing-masing seperti yang digambarkan diatas, dapat disimpulkan bahwa power militer dapat mempengaruhi kekuatan dan keberhasilan diplomasi negara disamping elemen-elemen yang lainnya. Negara dengan kekuaran militer yang kuat cenderung memiliki image sebagai kekuatan yang diperhitungkan oleh negaranegara lain, baik yang power militernya seimbang atau lebih kecil. Dengan postur kekuatan militer yang dimiliki saat ini, India lebih memungkinkan untuk menjaga kedaulatannya dengan lebih efektif dari serangan yang datang dari luar ketimbang Indonesia. Diplomasi India kepada negara-negara tetangganya juga lebih efektif dalam mencapai kepentingan nasionalnya dan mampu menciptakan stabilitas kawasan dengan menciptakan balance of power. Namun kekuatan ekonomi negara juga tidak dapat dipisahkan dari keberhasilan politik luar negeri atau diplomasi negara.

\section{Daftar Pustaka:}

The World's States' Military Power 2014 (India, Indonesia), http://www.global firepower.com/countrieslisting.asp?fb_action_ids $=653603291384975 \& \mathrm{f}$ b_action_types $=$ og.likes \&fb_source $=$ aggregation $\& \mathrm{fb}$ _aggregation_id= 28838148123782 , diakses tanggal 17 Juni 2014.

Top 10 Military Powers of the World, http://www.buzzle.com/articles/top10military-powers-of-the-world.html, diakses tanggal 17 Juni 2014.

Luerdi., Kebijakan Keamanan Nasional Pakistan Sebagai Respon Perjanjian Nuklir Sipil India-AS; 2005-2007, Skripsi, Jurusan Ilmu Hubungan Internasional, Universitas Riau, 2008. 
Griffits, Martin., Lima Puluh Pemikir Studi Hubungan Internasional, Edisi ke-1, PT.Raja Grafindo Persada, Jakarta, 2001.

Soeprapto, R., Hubungan Internasional; Sistem, Interaksi dan Perilaku, PT. Raja Grafindo Persada, Jakarta, 1997.

Roy, S.L., Diplomasi, Edisi ke-1, Rajawali Pers, Jakarta, 1991.

India as a great power., http://www.economist.com/news/briefing/21574458india-poised-become-one-four-largest-military-powers-world-end, diakses tanggal 16 Juni 2014.

Indian Navy developing new stealth ships., India Breaking News, http://www.youtube/Indian-Navy-developing-new-stealth-ships/, diakses tanggal 16 Juni 2014.

Moss, Trefor., Indonesia Military Powers Up, http://www.thediplomat.com/ Indonesia-Military-Powers-Up, diakses tanggal 16 Juni 2014. 